\title{
I don't Agree with Nick: Retrodicting the Conservative-Liberal Democrat
}

\section{Coalition}

TIM BALE

The BBC's political editor Nick Robinson knows Westminster as well as any journalist in the United Kingdom, and few can match his ability to communicate to millions in a way that combines accessibility with a subtle appreciation of the complexities of the issues at stake and the motives and moves of those involved. ${ }^{1}$ It is therefore with some trepidation that I argue that his assessment of the formation of the current coalition is flawed. For the BBC's man at the coal face, it had an awful lot to do with chemistry. For me, as a political scientist (albeit one who believes passionately in the value of both political journalism and contemporary history) it was, in the end, all about the physics and the maths. Both before and after the election I argued there was an alternative on offer. But everything I know about coalition formation in theory and in practice — especially when combined with what we all now know about the Liberal Democrat leaderships' policy preferences—-suggests that the outcome was utterly predictable or rather, since we are applying hindsight, retrodictable. ${ }^{2}$

What then did Nick Robinson argue? I take as my text his BBC documentary on the 'Five Days that Changed Britain', a flavour of which can be gleaned from his companion piece published on 29 July 2010 in the Daily Telegraph, in which he reminded us that it

It [was] a story of great drama. Nick Clegg was smuggled into Admiralty House for a secret meeting with David Cameron; Gordon Brown was so determined to avoid the cameras that he and Peter Mandelson squeezed along the tunnel under Whitehall which Churchill used to get to the bunker under the Ministry of Defence; Vince Cable was woken at 6am by a call from a Prime Minister pleading for his job; and David Cameron was forced to tell Her Majesty that he wasn't sure what sort of government he was going to form and that he might have to pop back to the Palace in the morning to clear things up. 
Despite this rollercoaster ride, some now argue that the outcome was inevitable. The parliamentary arithmetic, they argue, meant that the only available recipe for stable majority government was a Conservative/Liberal Democrat coalition. But that is not how it seemed to any of those I have interviewed.. ${ }^{3}$

Thrilling stuff — just as thrilling, indeed, as the even more detailed insider accounts that have appeared since. ${ }^{4}$ But even more thrilling — at least for someone who teaches politics for a living - is that the explanations the documentary went on to explore covered each and every one of what I explain to my first year students are the four basic types (or, if I'm feeling particularly pointy-headed, tropes) of political explanation. In no particular order, and in short, even truncated, form, these are: Structure: 'it's the economy stupid'; Institutions: 'them's the rules'; Agency: 'who did what, when and to whom?'; and Contingency: 'events, dear boy, events'. In Nick Robinson's account, these were fleshed out as follows:

- Structure: a widely shared fear among politicians and civil servants that some sort of 'Greek-style crisis' might overtake the United Kingdom drove the speedy formation of a government that was committed to cutting the deficit in double-quick time.

- Institutions: in the absence of any rules of the game that in some countries, say, dictate the appointment of someone charged with sounding out all the parties and then recommending to the Head of State how everyone should proceed, Clegg's preelection declaration that he would talk first to whichever was the largest party meant that the Tories were automatically granted first mover advantage.

- Agency: David Cameron's near-immediate and very public ‘big open and comprehensive offer', and the fact that he and his colleagues had clearly prepared for negotiations, stood in marked contrast to Brown's inertia and his evident failure, and that of his colleagues, to match that state of readiness. 
- Contingency: David Cameron and Nick Clegg had met by chance before the election campaign and concluded, albeit separately, that they could do business together - $\mathrm{a}$ personal chemistry matched by the mutual admiration of David Laws and George Osborne but which stood in marked contrast, say, to the charmless condescension of Ed Balls.

Clearly, none of the above was utterly irrelevant. Only a fool would argue that. But it was important only in the sense that it reinforced rather than undermined the logic of a Liberal Democrat-Conservative deal. And this logic was as overwhelming as it should have been obvious to anyone acquainted with the political science of government formation.

\section{Government formation: the academic evidence}

What then does the political science say? If we side-step the technical detail covered elsewhere in this volume, we can summarise years of theoretical and empirical enquiry into government formation as follows. ${ }^{5}$ Parties are primarily 'office-seeking': they want to run the country and they want to share the spoils of office, such as government jobs, with as few partners as possible. But parties are also 'policy seekers' and they worry about votes at the next election: as a result, they try if possible to team up with people of vaguely like-mind so that the legislation they introduce doesn't clash too glaringly with what their principles - or at least with what they claimed were their principles before going into government. This can be tricky for small and self-styled radical parties, but they often persuade themselves - and hope to persuade the electorate - that the compromises involved are justified by the good that they can do; they also gamble (on very little evidence incidentally) that they will earn 
brownie points for showing a sense responsibility, thereby overcoming widespread doubts about their fitness to govern.

Given all this, the rational option, where single party majority government is ruled out by the election result, is the 'minimum winning coalition' — a government that provides an overall majority to the smallest number of parties. Wherever possible these will be 'minimum connected winning coalitions', made up of parties apparently close enough to each other ideologically to avoid too many arguments over policy and stretching the credulity of voters too far. That said, governments of other types do occur-and more frequently than might be imagined. In European democracies between 1945 and 2003, just over 10 per cent of governments were single-party majorities, while a third were minimum-winning coalitions. ${ }^{6}$ However, just over a quarter of governments were minority governments—administrations which did not command an overall majority in the lower house of parliament — and a similar proportion were oversized (or 'surplus majority') coalitions_-governments which contained more parties than they needed to command such a majority. Taking only European Union countries at the end of 2009 (the latest point at which reliable data is easily available) the figures are single-party majority (12 per cent), minimum-winning coalition (42 per cent), minority government (31 per cent) and oversized coalition (15 per cent). ${ }^{7}$

Clearly the existence of oversized coalitions and minority governments needs some explaining. As regards the former, there are a number of reasons why they occur. For instance, deeply divided societies — those with large ethnic and/or linguistic minoritiesoften deliberately put together governments that will represent the nation as a whole, which can mean bringing parties who are arithmetically surplus to requirements into the fold. Or, perhaps, parties have fought the election in some kind of alliance meaning that if one enters government then the other has to be brought on board too. Occasionally, there is widespread 
agreement about a constitutional change which requires, say, a two-thirds majority, meaning that the government hoping to pass it will need more partners than, in normal circumstances, it would like. Sometimes parties going into government know they will have to make some tough choices and, realising they cannot rely totally on their own parliamentary supporters, they invite other parties to join them, thereby giving themselves a cushion and helpfully obliging their erstwhile opponents to dip their hands in the blood.

Minority governments have long fascinated political scientists: after all, why would any politician go for a government that can't command a majority in the house? Sometimes it is the only feasible option, in the sense that parties simply cannot agree on a majority solution but are prepared, for practical purposes at least, to tolerate a minority administration that, by its very nature, is unlikely to be able to ride roughshod over their preferences and interests. That said, minority government is more than a stop-gap solution in many Scandinavian countries - indeed, it is the norm in Denmark, and often occurs in Sweden and Norway. It becomes eminently possible in such countries because of the presence of a 'strong', often 'pivotal' party that sits in (or near the middle) of the parliamentary left-right spectrum - a party that all feasible majority coalitions would need to include, and/or can rely on the fact that the other parties in parliament (normally to its left and to its right) can't (or more accurately won't) cooperate with each other to beat it. In order to form and then persist, minority governments (which may be composed of a single party or may be a coalition) depend on one or more parties opting not to deny it a majority on 'confidence and supply' in other words, on the equivalent of a vote on the Queen's Speech or the basics of the Budget. An agreement to do that can be sought on an ad hoc basis or on a more contractual basis via a written agreement between the putative government and its 'support parties' (those parties that don't actually join the government but allow it to form and prevent it falling). ${ }^{8}$ Minority 
government is easier to engineer in some countries rather than others because of differences in the rules of the legislative game: most Scandinavian countries, like the United Kingdom (and New Zealand), operate 'negative parliamentarism' in that governments do not so much have to win a majority in crucial votes (the rule in some countries) as simply to avoid a defeat —a slightly lower hurdle to overcome.

\section{The appliance of science: forming the United Kingdom government in 2010}

It is important to understand all this because it explains why the prospect of a Conservative minority government was, whatever the media might have said and whatever some Tories may have thought or hoped, vanishingly small. A minority government, as we have seen, can only form in the first place if it can pretty much guarantee (not least to the Head of State responsible for appointing it) that it will not be defeated on motions of no-confidence and on its budget. Given most of the other parties in the House of Commons were located somewhere to the left of the Conservatives (even if only marginally), this was highly unlikely — unless the Liberal Democrats had been stupid enough (which they were not) to allow themselves to be lured into a confidence and supply arrangement that would have given them responsibility but no real power, risking a situation in which they would have shared the blame but not the spoils. Had that been the only deal on offer from Cameron then they might well have given more consideration to what was, on balance, the most feasible minority government — namely a Labour-Liberal Democrat coalition, relying on the votes or the abstentions (or even the partnership) of the assorted minor (mostly nationalist) parties. Given the Spanish experience, where minority governments routinely rely on the support of similar parties and survive their full terms, such a government would not necessarily have been unstable, especially if written agreements had been entered into, as is the case, for instance, in 
New Zealand (one of the many reasons why British civil servants were so interested in that case). ${ }^{9}$ More to the point, though, it would almost certainly have been allowed to form since the Conservatives could not, by themselves, have blocked it. A Tory minority government, without the support of the Liberal Democrats, could never have got its emergency budget or its Queen's Speech through Parliament. How, therefore, it could have formed in the first place (so that, supposedly, it could have 'challenged the other parties to vote it down') is hard to imagine.

What all this also points to is that the most powerful players during the Five Days in May were not the Conservatives but the Liberal Democrats. Without them, no governmentminority or majority — could feasibly have formed. What some political scientists would call their 'walk-away value' was therefore immense. David Cameron may have seized the initiative from Gordon Brown with his 'big, open and comprehensive offer' to the Liberal Democrats, but he did not in any way diminish Clegg's strength—a strength which, once again, we have to remember was not based so much on how many MPs he had (although this wasn't completely irrelevant), but on the fact that they sat between the two main parties and were bound to be courted by both of them. Into which suitor's arms they would fall, however, should never really have been in doubt. To Clegg and his team, concerned (indeed, more concerned than they had let on in public) about cutting the deficit, anxious to avoid a second election they had little or no money to fight, and well aware that a coalition with Labour would involve minority government with a bunch of politicians the public had clearly tired of, a minimum-winning coalition with the Conservatives was a no-brainer.

The only thing that might have prevented that outcome (which, insider accounts make it patently obvious, would have come about much sooner had it not been for Clegg's understandable desire to keeping Labour dangling so as to improve Cameron's offer and 
convince his troops that he had truly exhausted the alternatives) was the perceived ideological and policy differences between the two parties that formed the coalition. ${ }^{10}$ The keyword here, however, is 'perceived'. What blinded many analysts - including, mea culpa, mea maxima culpa, this one - to what in hindsight is the bleedin' obvious was the mistaken impression that the Liberal Democrats were an irretrievably left-of-centre outfit. ${ }^{11}$ This was based on a superficial sense of their slogans and a failure both to appreciate the significance of Nick Clegg's victory in the party's leadership contest and to pick up on just how much (under the radar) the party was changing organisationally and ideologically. ${ }^{12}$ Those who knew the Liberal Democrats better - and one has to include in that number key Conservatives like Oliver Letwin, George Osborne and naturally David Cameron himself-were not so blinkered. They realised, almost certainly before the election, that they could shoot not just for a minimum-winning coalition, but for a minimum connected winning coalition —an arrangement that the Liberal Democrat leadership could, with considerably less embarrassment and difficulty than many commentators had wrongly assumed, sell to MPs and to the grassroots, even if some of those who had voted for the party (particularly those who had leant it their anti-Tory tactical support) were always going to be less easy to convince.

What Cameron and co. could not perhaps have realised, although they must have hoped it would be the case, was the extent to which Clegg and co. had completely swallowed the Conservatives' economic analysis and would then go on to underplay their hand. I for one find it difficult to conceive that a continental European party in the same position as the Liberal Democrats would have negotiated a deal which left all of the high offices of state in their partners' hands, left that partner in full control of fiscal and economic policy, made it chiefly responsible for devising and implementing a policy (university tuition fees) that made 
a mockery of its prior commitments, and offered it so few tangible policy wins on which to fight the next election. Partly, of course, that is because most continental European parties are not, like the Liberal Democrats, new to this game: Germany's liberal party, the Free Democrats, are old hands and were arguably able in 2009 to secure a much better deal not only than their British sister party, but also the similarly inexperienced German Greens back in 1998. That said, the deal the Liberal Democrats got in 2010 was so poor that it is difficult to resist the temptation to suggest that what happened was what always happens when vegetarians negotiate with carnivores.

We should remind ourselves that in every democracy parties trade off policy, office and votes, but they don't always get those trade offs right: for all its tradition of coalitionmaking, for example, the German Free Democrats still found their opinion poll rating plunging (all though not necessarily irrecoverably) soon after they went into government with Angela Merkel's Christian Democrats. And there is also a more rational explanation, apart from sheer lack of nous and pressure of time, for why the Liberal Democrats secured so little. Perhaps they believed that, even if it gave them so few obvious goodies and even if it failed to deliver them electoral reform, the deal itself would earn them the gratitude of the electorate for acting responsibly and in the national interest, as well as finally put paid to the common wisdom that a vote for the Liberal Democrats was a vote wasted. Unfortunately for them, the evidence from other countries is not particularly encouraging on this score.

While it is undoubtedly true that one of the best predictors of being invited into a coalition government in the future is whether a party has served — and served reliably — in a coalition in the past, voters in the short term do not tend to reward parties (particularly small, self-styled radical parties) for going into government. If anything the reverse is true. And parties new or at least unfamiliar with government often find it more difficult than their more 
experienced (and normally bigger) coalition partners to maintain their unity, not least because dropping a few percentage points in the polls can't be so easily shrugged off when those few points may mean the difference between survival and parliamentary oblivion — or at least a return to the days (familiar to the Liberals) where your MPs can all fit into the one taxi-cab. The Liberal Democrats' chaotic split over tuition fees in early December 2010 — not much more than six months into the coalition —-wasn't (to borrow from Churchill) necessarily the beginning of the end, but it was certainly the end of the beginning.

\section{Conclusion}

The main point of this excursion into the political science of government formation, however, is not to poke fun at the Liberal Democrats or to predict their eventual demise. It's not Nick Clegg I want to disagree with, after all, but Nick Robinson. As someone who has enormous admiration for the job that he and his fellow journalists do, and as someone who feels strongly that academics need to engage both with the media and the politicians who make the calls that we are all so interested in, I feel ambivalent about arguing that an explanation of the outcome of those Five days in May doesn't really need that much close contact and contextual detail—especially because I myself clearly failed to see it coming. But that was because I, like others, allowed what I wrongly thought of as an insuperable obstacle to the eventual outcome - the presumed policy gulf between the Liberal Democrats and the Conservatives - to obscure a deeper truth, namely that such an outcome, knowing what we know about the political science of government formation, was all but unstoppable. The only way anything other than a Conservative-Liberal Democrat coalition could have resulted would have been if all the factors Nick Robinson focused on (the economy, the rules of the game, the actors involved, the chemistry and the contingency) had pointed in some other 
direction. But they didn't. The drama and the detail are fascinating — so fascinating that a film version starring Michael Sheen as David Cameron (or Nick Clegg, or both) is surely only a matter of time. But, in the end, the drama and the detail only served to make the all-butinevitable inevitable.

\section{Notes}


${ }^{1}$ Overseas readers unfamiliar with the man in question can find out about him at http:// en.wikipedia.org/wiki/Nick_Robinson

2 T. Bale, 'If not Clameron or Clown, how about the Spanish option?', guardian.co.uk, 8 May 2010 .

${ }^{3}$ N. Robinson, 'How the Coalition government was formed', Daily Telegraph, 29 July 2010.

${ }^{4}$ See, for example, D. Laws, 22 Days in May, London, Biteback, 2010; R. Wilson, 5 Days to Power, London: Biteback, 2010.

${ }^{5}$ The literature is massive. The most accessible short introduction probably remains, L. de Winter, 'Parties and government formation, portfolio allocation and policy definition', in K. R. Luther and F. Müller-Rommel, eds, Political Parties in the New Europe: Political and Analytical Challenges, Oxford, Oxford University Press, 2003, pp. 171-206. One should then progress onto W. C. Müller and K. Strøm, eds., Coalition Governments in Western Europe, Oxford, Oxford University Press, 2003; W. C. Müller, K. Strøm and T. Bergman, eds, Cabinets and Coalition Bargaining: The Democratic Life-cycle in Western Europe, Oxford, Oxford University Press, 2008. See also L. W. Martin and R. J. Stevenson, 'Government formation in parliamentary democracies', American Journal of Political Science, vol. 45, no. 1, 2001, pp. 33-50. Anyone interested in the history of coalition government in the United Kingdom should consult M. Oaten, Coalition: The Politics and Personalities of Coalition Government from 1850, London, Harriman House, 2007.

${ }^{6}$ See M. Gallagher, P. Mair and M. Laver, Representative Government in Modern Europe, London, McGraw-Hill, 2005.

7 T. Bale and D. Caramani, 'Political data in 2009', European Journal of Political Research, vol. 49, nos 7-8, 2010, pp. 855-67.

${ }^{8}$ See T. Bale and T. Bergman, 'Captives no longer, but servants still? Contract parliamentarism and the new minority governance in Sweden and New Zealand', Government and Opposition, vol. 41, no. 3, 2006, pp. 422-49.

${ }^{9}$ Cabinet Secretary Sir Gus O'Donnell visited New Zealand before the election (see http:// network.civilservicelive.com/pg/pages/view/367305/). Those involved would also have seen B. Yong, 'New Zealand's experience of multi-party governance', in R. Hazell and A. Paun, eds, Making Minority Government Work, London, Institute for Government/Constitution Unit, 2010, pp. 38-53.

${ }^{10}$ Wilson, 5 Days to Power, pp. 120, 136-7, 139, 152, 170, 228, 234-8, 252, 292.

${ }^{11}$ T. Bale, ‘A Lib Dem-Tory deal won’t work', guardian.co.uk, 3 May 2010.

${ }^{12}$ For details see, E. Evans and E. Sanderson-Nash, 'Sandals to suits: professionalization, coalition and the Liberal Democrats', British Journal of Politics and International Relations, forthcoming. 